\title{
Research stand with electrodynamic brake
}

\section{Stanowisko badawcze z hamulcem elektrodynamicznym}

\author{
KRZYSZTOF NALEPA \\ WOJCIECH MIASKOWSKI \\ MARZENA WILAMOWSKA-KORSAK \\ PIOTR PUCHOWSKI *
}

\begin{abstract}
The article presents the design and characteristics of the eddy current electrodynamic brake used in the system working with an asynchronous motor. The construction of the stand allows the determination of the characteristics of electric motors in combination with the regulated mechanical load in the form of an electrodynamic brake. The presented electrodynamic brake allows precise adjustment of the torque loaded on the tested motor. It allows the load up to $10 \mathrm{Nm}$ at speeds ranging from 100 to $1500 \mathrm{rpm}$.

KEYWORDS: eddy current, electrodynamic brake
\end{abstract}

Eddy current brakes fulfill a function similar to the friction brakes (which are most common), but to produce braking force they use the physical phenomena occurring in the conductor moving in the electromagnetic field. The electromagnetic field induces a voltage in each metal element that moves perpendicular to the line of the field. The induced voltage is the source of the vortex currents, producing an electromagnetic field that counteracts the source field and thus produces a force whose one component is opposed to the direction of travel of the braked element [1, 2].

\section{Design and construction of the brake}

A braking system belonging to the group of wheel type brakes was mounted on the stand. The brake forces the tested motor to the torque it produces. The functional premise was to develop and build a stand that would allow testing of drive systems (wind motors) and low power generators. It was necessary to develop an electrodynamic brake and to examine its actual parameters and scope of application for the first purpose.

The measuring stand consists of the following units: - eddy current brake with adjustable power supply, - power unit consisting of an engine and a power unit, - measuring devices,

- basics of the stand.

The view of the complete stand is shown in fig. 1.

The brake work assembly is made up of modules consisting of two units:

- power unit, including caged asynchronous motor powered by the inverter;

- brake assembly incorporating an electrodynamic brake and adjustable DC power supply.

\footnotetext{
* Dr inż. Krzysztof Nalepa (nalepka@uwm.edu.pl), dr inż. Wojciech Miąskowski (wojmek@uwm.edu.pl), dr inż. Marzena Wilamowska-Korsak (wilam@uwm.edu.pl), dr inż. Piotr Puchowski (piotr581@wp.pl) - Wydział Nauk Technicznych Uniwersytetu Warmińsko-Mazurskiego
}

The modular construction of the stand ensures its versatility. The stand can be used to test:

- propulsion systems - after replacement of the propulsion system shown here, tested propulsion system; the brake serves to load the mechanical drive under test;

- low-speed generators of electricity - the electrodynamic brake is removed, and in its place is assembled a circular electricity generator; drive system with cage motor and inverter provides torque with variable rotational speed control.

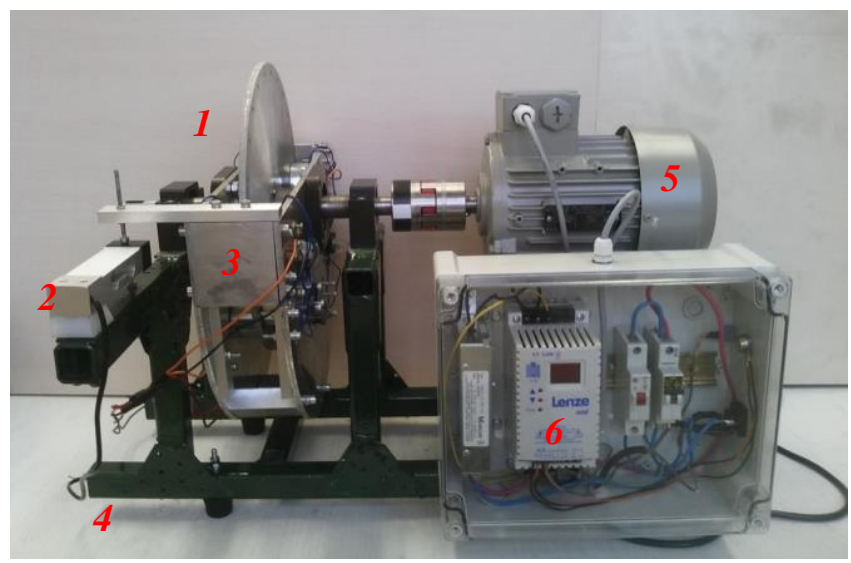

Fig. 1. View of the complete stand for testing the eddy current brake: 1 - brake disc, 2 - load cell, 3-yoke with electromagnets, 4-stand, 5 - motor, 6 - inverter

The system was manufactured by Siemens, a starlinked three-phase asynchronous 1LA7083-4AA10-Z engine with a rated power of $0.75 \mathrm{~kW}$ at a rotational speed of $1395 \mathrm{rpm}$ and a rated torque of $5.1 \mathrm{Nm}$. The drive engine is compatible with the Lenze smd inverter, providing smooth control over the entire engine speed range.

The braked element, made in the form of an aluminum homogeneous disc, is provided with a shaft mounted in the housing. On the sides, 12 ITS-MS-5030 electromagnets, attached to the aluminum side covers, were placed at the bottom of the element. There are six electromagnets on each side of the dial. Side covers are the elements of the brake frame with which the arm extends into the strain gauge.

Two main parameters were tested on the stand: the braking torque observed as the force acting on the fixed arm and the rotational speed.

The first parameter was measured using a strain gauge type BTENS-N1-020.

The arm attached to the brake housing directly affected the strain gauge beam. The signal from the beam was sent to the ADT1-U measuring module from Wobit, which 
was connected to a computer with the MDT100T-PC monitoring program installed.

The rotational speed was measured with a Sentry ST723 contact-free tachometer.

The base was made as a welded construction of $30 \times$ $30 \mathrm{~mm}$ steel profiles and a $3 \mathrm{~mm}$ wall thickness. Four support elements were used, resembling the inverted letter "U". The lower two are the backrest for the engine and two higher - for the brake. The carriers were welded to the "H"-like base, and the base was set on four vibration-isolating feet to provide stable and safe operation during the test.

The profiles were made of structural steel S235359 with the parameters given in the Table I.

TABLE I. Parameters of structural steel $\mathbf{S 2 3 5 3 5 9}$

\begin{tabular}{|l|c|}
\hline Elasticity coefficient, $\mathrm{N} / \mathrm{m}^{2}$ & $2.1 \mathrm{e}+011$ \\
\hline Poisson's ratio & 0.28 \\
\hline Shear stress ratio, $\mathrm{N} / \mathrm{m}^{2}$ & $7.9 \mathrm{e}+010$ \\
\hline Specific weight, $\mathrm{kg} / \mathrm{m}^{3}$ & 7700 \\
\hline Tensile strength, $\mathrm{N} / \mathrm{m}^{2}$ & 723825600 \\
\hline Tensile strength, $\mathrm{N} / \mathrm{m}^{2}$ & 723825600 \\
\hline Plasticity limit, $\mathrm{N} / \mathrm{m}^{2}$ & 620422000 \\
\hline Coefficient of thermal expansion, $1 / \mathrm{K}$ & $1.3 \mathrm{e}-005$ \\
\hline
\end{tabular}

\section{Base strength analysis}

Strength analyzes have been carried out, taking into account the static loads and workloads of the workstation, to check the structural durability and to determine whether the entire system is safe for the user during operation. Solidworks with Simulation was used for analysis.

Analysis of the statically loaded construction is to check the deformation of the base caused by the weight of the brake and the engine. The analysis was divided into four more detailed studies. The first three strengths were 250 $\mathrm{N}$ and equaled the sum of the thrust forces exerted by all attached elements. In the fourth study, there was simultaneous interaction of identical loads along all three axes. The sum of the force components was $250 \mathrm{~N}$. At the same time, a longer and shorter support was applied to each test. This paper presents the results of the combined force interaction (fig. 2 and fig. 3).

The strength analysis of load cases resulting from the work of the station allowed us to check the strength of the structure for maximum loads caused by the influence of the braking force on the arm of the load cell. The maximum torque that a motor can produce is $15 \mathrm{Nm}$. Based on calculations made in the Solidworks environment, this torque can generate at the end of the arm a maximum thrust force of $91 \mathrm{~N}$. Due to the versatility of the post, the beam loading force has been increased three times - up to $273 \mathrm{~N}$. As a result, the stress distribution in the components and the value movements. In each study, gravity was also taken into account. Finite element mesh parameters used in the analyzes are given in Table II.

\section{TABLE II. Finite element mesh parameters}

\begin{tabular}{|c|c|c|}
\hline \multicolumn{2}{|l|}{ Grid type } & Solid grid \\
\hline \multicolumn{2}{|l|}{ Used grid generator } & Standard grid \\
\hline \multicolumn{2}{|l|}{ Automatic transition } & Disabled \\
\hline \multicolumn{2}{|l|}{ Include automatic grid loops } & Disabled \\
\hline \multicolumn{2}{|l|}{ Jacobian points } & 4 poinst \\
\hline \multicolumn{2}{|l|}{ Element size, $\mathrm{mm}$} & 9.82939 \\
\hline \multicolumn{2}{|l|}{ Tolerance, $\mathrm{mm}$} & 0.49147 \\
\hline \multicolumn{2}{|l|}{ Grid quality } & High \\
\hline \multicolumn{2}{|l|}{ Total number of nodes } & 63096 \\
\hline \multicolumn{2}{|l|}{ Total number of elements } & 31916 \\
\hline \multicolumn{2}{|l|}{ Maximum aspect ratio } & 15.082 \\
\hline \multirow{2}{*}{$\begin{array}{l}\text { Percentage of elements with a } \\
\text { shape factor of }\end{array}$} & $<3$ & 35.3 \\
\hline & $>10$ & 0.0815 \\
\hline
\end{tabular}

The maximum stress in the modeled base was 6.8223 $\mathrm{MPa}$ and the maximum displacement was $0.0221 \mathrm{~mm}$ (fig. 2). In turn, the maximum stress in the beam of the strain gauge beam was 22.63 $\mathrm{MPa}$ and its maximum displacement was $0.079 \mathrm{~mm}$.

In no case was the yield strength exceeded, i.e. 620.42 $\mathrm{MPa}$. The maximum value in static tests was $14.38 \mathrm{MPa}$, while in dynamic tests - $22.63 \mathrm{MPa}$. The largest displacement was $0.079 \mathrm{~mm}$ (dynamic load test). The displacement values do not exceed a pre-set value of 0.5 $\mathrm{mm}$.

a)

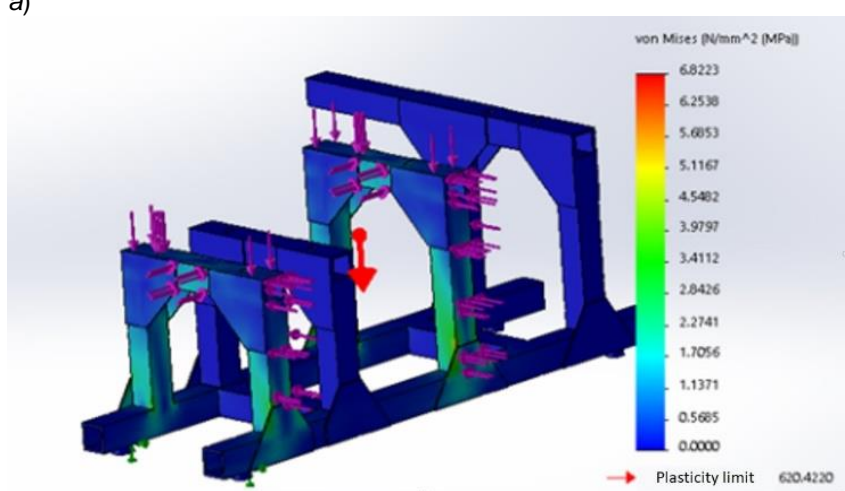

b)

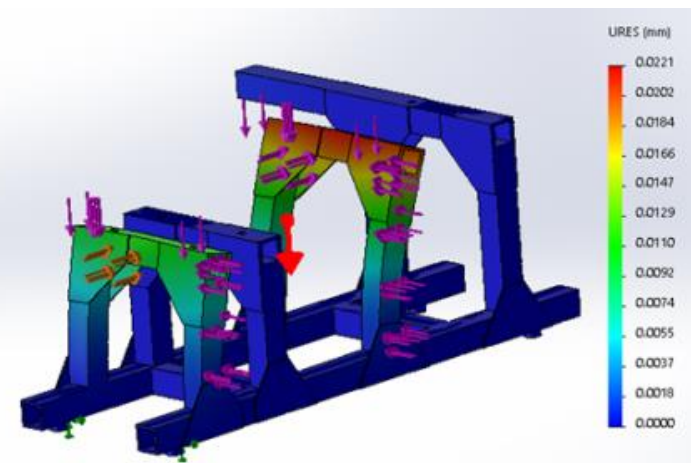

Fig. 2. Sum values of stresses (a) and displacements (b) of the base elements

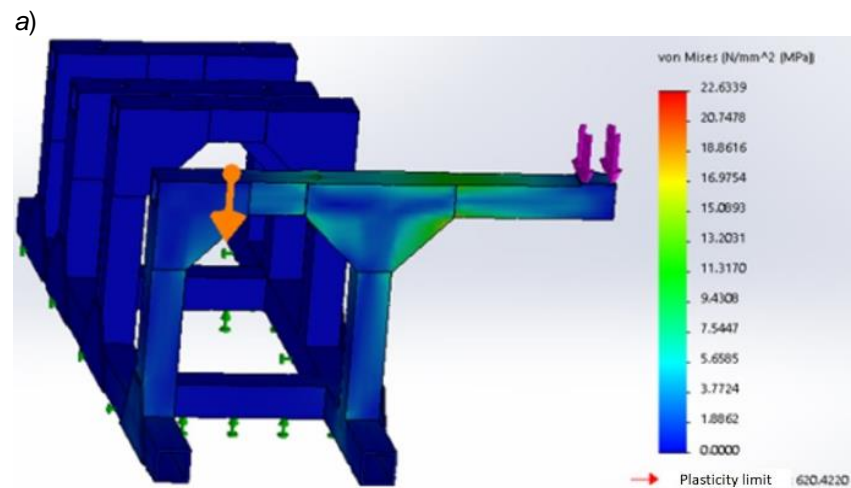

b)

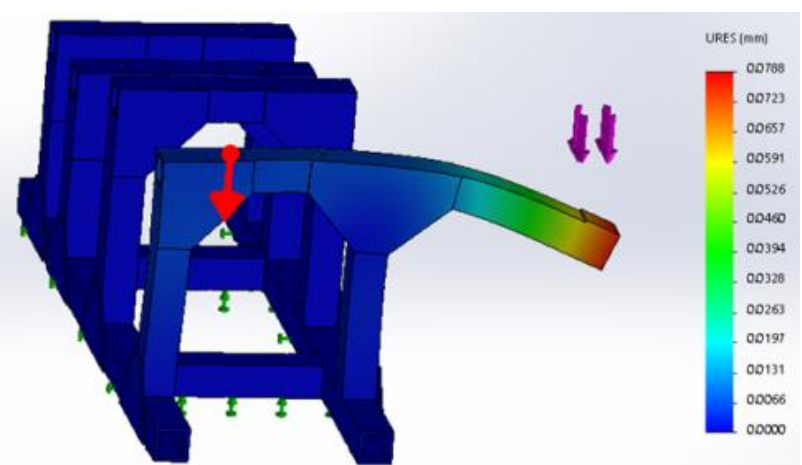

Fig. 3. Sum values of stresses (a) and displacements $(b)$ of strain gauge beam 


\section{Examination of the eddy current brake}

The tests for ten inverter settings for the asynchronous motor were performed: $5,10,15,20,25,30,35,40,45$ and $50 \mathrm{~Hz}$. They are synchronous speeds: 150, 300, 450, $600,750,900,1050,1200,1350$ and $1500 \mathrm{rpm}$. The tests were carried out successively for a fixed value of motor current. During testing, the frequency value of the inverter was set and the brake voltage applied to the brake solenoids was changed from 0 to $20 \mathrm{~V}$, thus causing the mechanical load on the motor. The force value was read using a strain gauge and the speed value was measured using a tachometer.

The results of the brake test - the family of brake characteristics for the adjustable supply current frequencies - are shown in fig. 4. Fig. 5 shows the dependence of the maximum torque obtained with the supply voltage of $20 \mathrm{~V}$.

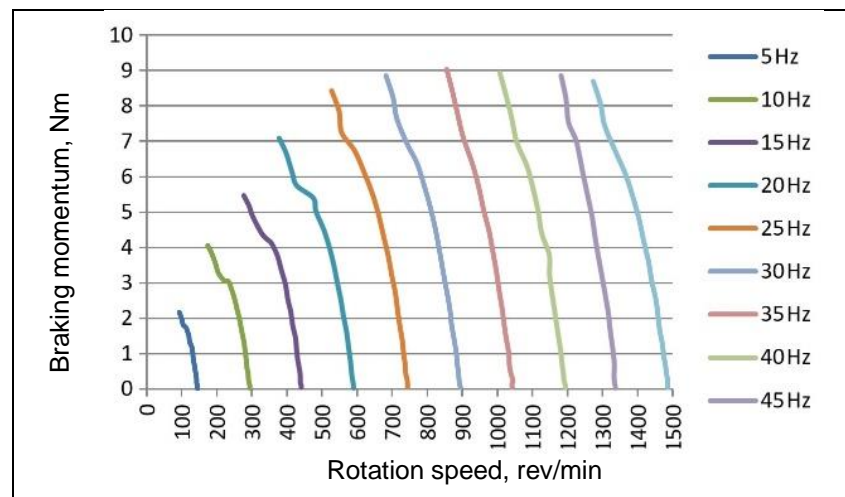

Fig. 4. Brake torque characteristic produced when supplying the brake with voltage from 0 to $20 \mathrm{~V}$ at various settings of motor inverter $(5 \div 50 \mathrm{~Hz})$

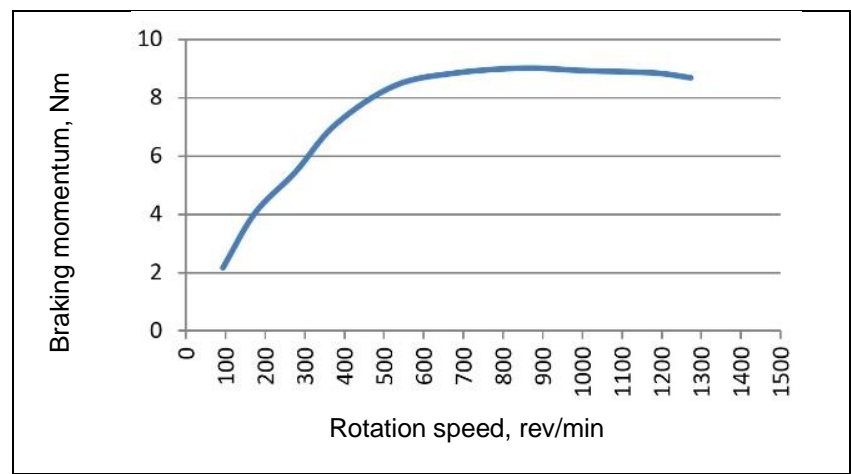

Fig. 5. Maximum braking torque generated during brake operation at $20 \mathrm{~V}$ supply voltage

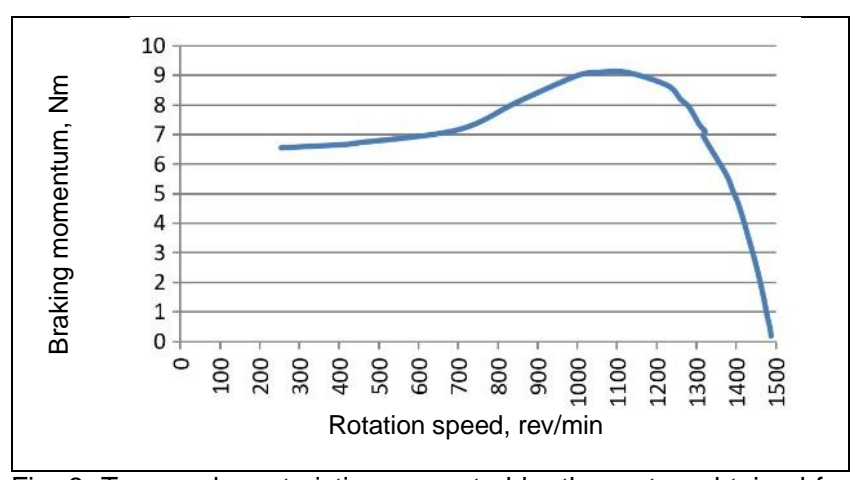

Fig. 6. Torque characteristics generated by the motor, obtained for the application of an electrodynamic brake

One of the functionalities of the presented stand is the possibility of testing propulsion systems. An engine with an electrodynamic brake was tested. The sample characteristics of the test torque of the Siemens 1LA7083$4 A A 10-Z$ engine as a function of the rotational speed are shown in fig. 6. The tests were performed for a set frequency of $50 \mathrm{~Hz}$ (synchronous speed $1500 \mathrm{rpm}$ ) - the motor was loaded until a load torque of equal critical value, followed by a decrease in the driving torque generated by the engine.

\section{Conclusions}

The test stand presented in this paper has been designed and built to test drive systems in the form of wind turbine models that are to be used to convert wind energy into quasi-autonomous lighting or signaling points (electrodynamic brake module), intended for lighting or signaling points (stand with drive module, suitable for testing generators).

The presented characteristics illustrate the range of applicability of the electrodynamic brake. It allows precise adjustment of the torque loaded on the tested engine and provides a load of up to $10 \mathrm{Nm}$ at speeds ranging from 100 to $1500 \mathrm{rpm}$.

The presented works were carried out within the framework of the project Functional models and studies of the construction of a quasi-autonomous lighting or signaling point (decision of the Minister of Science and Higher Education No. 5119/B/T02/2011/40 of 2011-02-04).

\section{REFERENCES}

1. Skowron J. „Badanie wpływu indukcyjności na charakterystykę hamulca wiroprądowego". Symulacja w Badaniach i Rozwoju. 1, 1 (2010): s. 85-92.

2. Skowron J. „Hamulce elektromagnetyczne w pojazdach szynowych". Symulacja w Badaniach i Rozwoju. 3, 3 (2012): s. 159-167. 